\title{
Political entrepreneurship: entrepreneurship ecosystem perspective
}

\author{
Maksim Belitski ${ }^{1,2}$ D Ana-Maria Grigore ${ }^{3} \cdot$ Anca Bratu $^{3}$
}

Accepted: 30 March 2021 / Published online: 16 April 2021

(c) The Author(s) 2021

\begin{abstract}
We use the entrepreneurial ecosystem perspective to study political entrepreneurship as a form of alignment between disruptive and unproductive entrepreneurs with authorities aiming to get privileged access to resources. Political entrepreneurship (PE) has emerged as a phenomenon in transition and developing economies and may compromise the entrepreneurial ecosystem (EE) objectives. Combining interview and survey data, this study provides an in-depth assessment of entrepreneurial ecosystems in a transition economy and the role that political entrepreneurs play in moderating the effect of resources on the quality of entrepreneurship. Our findings are generalizable to other transition and developing economies as we demonstrate what various configurations of factors increase stakeholders' perception about EE and directly affect its quality. Our findings reveal that stakeholders appreciate the evolution trends towards mature and productive entrepreneurship, but the progress is slow, nonlinear, with setbacks, still seriously threatened by corruption, lack of competence, and the interference of the political factor as well as regional differences. This study offers implications on how to adopt a place-based and holistic approach to institutional reforms when policymakers aim at creating productive entrepreneurial ecosystems. This study implications are in the adoption of a place-based and holistic approach to institutional reforms when policymakers aim at creating productive entrepreneurial ecosystems. While political entrepreneurship may significantly distort an ecosystem, this study offers recommendations to managers and policymakers who plan to start a business in an environment with weak institutions and the rule of law.
\end{abstract}

Keywords Entrepreneurial ecosystem · Political entrepreneurship · Stakeholders · Corruption · Transition economy

Maksim Belitski

m.belitski@ reading.ac.uk; mbelitski@groupe-ige.fr

Extended author information available on the last page of the article 


\section{Introduction}

In Schumpeter's (1934) study, innovation and entrepreneurship are intimately connected. Yet, only a minority of entrepreneurs introduce new to market products, and entrepreneurs differ widely in terms of their economic impact (Baumol, 1990; Weitzel et al., 2010; Autio et al., 2014). In this study, we build on Baumol's theory of productive and unproductive entrepreneurship, postulating a mechanism to connect entrepreneurial behavior and resources available within an ecosystem with the entrepreneurial ecosystem performance and, therefore, potentially with an economic impact.

Entrepreneurship ecosystems (EEs) is often called a "new buzzword" among researchers and managers (Spigel \& Harrison, 2018; Brown \& Mason, 2017) or "word du jour" (Lowe \& Feldman, 2017) and the latest industrial policy "blockbuster" (Brown \& Mawson, 2019). However, moving ecosystem from a buzzword to an instrument of regional economic development (Audretsch \& Belitski, 2021) needs a more systematic approach, "to both aid regions in building an effective entrepreneurial ecosystem, but also to identify when such developments might not be feasible" (Spigel et al., 2020: 487), as as well as to understand how entrepreneurship type (Baumol, 1990; Stam et al., 2011) e.g., unproductive vs. productive entrepreneurship can impede or facilitate the outcome of EE.

While prior research that focused on the assessment of framework and systemic conditions for entrepreneurial aspirations and growth-orientation of entrepreneurs (Stam et al., 2011; Acs et al., 2013; Kolvereid \& Isaksen, 2017; Mthanti \& Ojah, 2017), there has been a lack of research on factors that may threaten the quality of the ecosystem, in particular, the effect of unproductive and destructive entrepreneurship behavior of stakeholders (Desai \& Acs, 2007; Desai et al., 2013) which in transition and emerging economies has been known as "political entrepreneurship".

Drawing on the entrepreneurial ecosystem framework (Isenberg, 2010; Audretsch \& Belitski, 2017; Bosma et al., 2018) we argue that the rent-seeking behavior of some economic agents may challenge the potential of the free-market mechanisms and reduce the productivity of an entrepreneurial ecosystem as a whole. The gap in the literature persists.

This paper's purpose is to contribute to the institutional and entrepreneurship literature by demonstrating how destructive entrepreneurs who align with corrupt policymakers for "political entrepreneurship" may distort the EE. Political entrepreneurship as an institutional phenomenon has been particularly underresearched in developing and transition countries where "political entrepreneurship" has emerged as a new transition to the market phenomenon. In doing so, we bring together previous research on corruption and entrepreneurship (Chowdhury et al., 2015; Belitski et al., 2016) and formal and informal institutions in the entrepreneurial ecosystem (Brown \& Mason, 2017; Stam \& Van de Ven, 2020).

Political entrepreneurship is a regional issue in emergent economies - especially in post-communist countries where a significant number of former "apparatchiks" - clerks with strategic positions in the administration or in the secret 
services, have built a system of ambiguous and elliptic legislation rapidly, engineering a privileged system that allows to tackle the "market" economy and use strong social ties to achieve economic goals. This type of entrepreneurship unfavorably influences entrepreneurial activity and economic growth (Shleifer \& Vishny, 1993; Kaufmann \& Siegelbaum, 1997).

Thinking of the most appropriate unit of analysis for this study, we embrace and emphasize that the emergence of entrepreneurial ecosystems comes not just from the recognition that places matters for entrepreneurs but also that entrepreneurs matter for the place (Bosma \& Sternberg, 2014). Prior empirical studies confirmed that the location is important for examining EEs (Spigel, 2017; Villegas-Mateos, 2020). Therefore, in this study, we focus on the regional aspects of EE analysis from the city perspective rather than regional industrial clusters or national EEs (Autio et al., 2014).

The entrepreneur is a member of a community, of a system, of an environment from which they receive substance and must contribute. Most important: the entrepreneur must design a strategy that makes it viable for her or his business, or he or she wouldn't have a business at all.

This study is also a call to policymakers to focus on city-regions, where specific resources and strengths can be allocated and capitalized (Katz \& Bradley, 2013). This is because national-level data could hide a great deal of variation between city-regions (Spigel et al., 2020). We should consider the cities as the most appropriate EE research units (Bosma \& Sternberg, 2014; Content et al., 2019).

Our study makes two important contributions to regional entrepreneurship literature. First, we introduce the concept of "political entrepreneurship" to the entrepreneurship ecosystem and examine empirically how political entrepreneurs may distort the macrosystems in transition economies with links to politicians consistently influence EE stakeholders' performance and access to resources. We demonstrated how EE pillars are moderated by political entrepreneurship as a set of formal and informal institutions in the process of value creation and securing the competitive advantage of the entire EE.

Second, we addressed the gap in research on EEs in transition economies that western scholars have overlooked, particularly the role of the institutional context in growth-orientation and quality of EE. We demonstrated that differences in institutional arrangements in transitional economies and their preserved communist legacy (Fan et al., 2019) have significantly affected how EE is created, develop, and function.

The framework developed in this study can be used to expand what we know about EE in transition economies and the perspective of entrepreneurs that not only positively contribute to growth (productive entrepreneurs) but within the spectrum of political entrepreneurship as an element of $\mathrm{EE}$ in developing and transition economies. Our results demonstrate how a variety of ecosystem characteristics may affect its quality as well the role of political entrepreneurship and corruption moderating this relationship. We demonstrated that political entrepreneurship and corruption had been institutionalized (Cuervo-Cazurra, 2006) in the context of the transition economy. 
The subsequent sections are structured as follows. In the next section, existing research on EEs is reviewed. Third Section introduces the context of Romania as a transition economy. Fourth Section describes the data and methodology we used. Fifth Section presents qualitative and quantitative results, while Sixth Section discusses them and concludes by suggesting directions for further research.

\section{Literature review}

\section{An entrepreneurial ecosystem framework}

We start by discussing the role that economic actors and entrepreneurs play in the ecosystem (Brown \& Mason, 2017; Stam \& Van de Ven, 2020) and their contribution to entrepreneurial outcomes (Stam, 2018; Audretsch et al., 2019a).

Recent research has focused on EE, highlighting the role that local and institutional contexts play for entrepreneurs (Malecki, 2018; Audretsch et al., 2019b; Bogers et al., 2019). EE embraces research on the geography of entrepreneurship from a systemic perspective (Audretsch \& Belitski, 2017; Acs et al., 2017; Theodoraki and Messeghem, 2017; Spigel \& Harrison, 2018; Szerb et al., 2019; Miles \& Morrison, 2018). The approach has changed since it was first introduced by Iansiti and Levien (2004), Isenberg (2010), and Feld (2012), which now includes additional pillars and the role that combinations of different factors and motives for entrepreneurs play in EE (Audretsch et al., 2019a; Kremer, 2019).

As Moore (1993) understood, an ecosystem consists of an active relationship between a considerable number of its inhabitants. Their continuous interactions make life possible and evolving in that very particular environment, associating the behavior of an entrepreneurial conglomerate confined in a region, including various actors connected in complex relationships (Godley et al., 2019). The interesting point we would like to make that any actions that are carried out against the natural ways in the ecosystem and that do not facilitate its natural growth path are doomed to fail - sooner or later.

Observing natural systems (Moore, 1993), we can understand the right paradigm of evolution, with all its setbacks, failures or the happy-endings. Both categories that we compare are essentially systems: therefore, they obey the universe's laws: the thermodynamic laws (about energy and entropy), its statistic, and philosophic principles. Both are open systems, with fuzzy borderlines; they overlap continuously with other systems, exchanging information.

To better understand, the EE concept is the subject of much debate among network researchers, urban economists, systems theorists and cluster researchers (Autio et al., 2014; Pugh et al., 2019). At the same time, Spigel and Harrison (2018) state that an entrepreneurial ecosystem is "a unique domain, distinct from related work on clusters and regional innovation systems" (Spigel \& Harrison, 2018: 152). While many researchers would call it "old wine in new bottles concept" (Stam, 2018), ecosystems this is what Porter (1998) would call clusters that focus on "geographic concentrations" of companies, suppliers, service providers, and firms and institutions in related industries, who can be both be competitors and partners. 
Entrepreneurship ecosystems are often perceived as regional innovation systems (Autio et al., 2014), which is a different phenomenon and is generally referred to as a regional network of institutions that link "knowledge production" in academia and other agents of research with firms that innovate, increasing, in the end, a region's overall innovativeness (Nicotra et al., 2017; Spigel \& Harrison, 2018).

Depending on the ecosystem's stage (Szerb et al., 2019), there are many types of EEs, and simple analysis of them shows that there is considerable heterogeneity in the way specialists perceive but especially define EEs. While some underline the power of interrelationships and inter-conditioning between different factors, actors, and processes (Isenberg, 2011; Brown \& Mason, 2017; Audretsch \& Belitski, 2017), others emphasize the importance of key elements (Roundy et al., 2017; Spigel, 2016). For instance, in Spigel's view, “ecosystems represent the regional economic, social and cultural environment within a region that provides support and resources for growth-oriented entrepreneurs" (Spigel, 2016: 142), and Stam considers EEs as a "set of interdependent actors and factors coordinated in such way that they enable productive entrepreneurship" (Stam, 2015: 1765). This statement raises an important question of whether productive entrepreneurship - as Baumol (1990) would understand - is necessary for EE to exist. Would EE exist by satisfying needs for both necessity and opportunity entrepreneurs, productive and unproductive entrepreneurs? There has been no research and no answer to this question.

These tensions raise a significant criticism about the definitions of EE and its sustainability and public support to EE. Kuckertz (2019) argues the understanding of EE is still "vague and opaque"; other limit EEs to geographic boundaries of cities (Audretsch \& Belitski, 2017), which makes it difficult to assess and measure EEs (Brown \& Mason, 2017). In most studies, the entrepreneurial ecosystem is considered "a spatially, relationally and socially embedded phenomenon" (Brown \& Mawson, 2019: 3). Hence some recent research specialists claim that the EE is not a coherent theory but rather a "conceptual umbrella" comprising a plethora of perspectives on entrepreneurship geography (Spigel, 2016).

We agree that the "optimal" "system of entrepreneurship" has as its main function the development of entrepreneurial activities, entrepreneurial growth, productivity, job creation as well as discovery and exploitation of entrepreneurial opportunities for (regional) economic development (Audretsch \& Lehman, 2005; Feldman, 2014). It is part of a general trend to conceive innovation processes as systematic processes involving many - connected - actors, institutions, and processes (Acs et al., 2014).

The methodology to study EE is also very different. For instance, the research by Neck et al. (2004) refers to EE as the Boulder region in Colorado, while Cohen (2006) concentrates on Victoria, British Colombia. While case studies allow going in-depth of ecosystem nature, an increasing number of studies examine EEs matching the theoretical to empirical perspective; most studies apply a quantitative approach using the databases from the Global Entrepreneurship and Development Institute (Kremer, 2019), from the Global Entrepreneurship Monitor (Szerb et al., 2013; Simmons et al., 2019) or Eurostat (Bruns et al., 2017; Audretsch \& Belitski, 2017). For example, empirical data show stark differences among regions and within countries and regions in Europe in the number of start-ups or businesses' growth (Fritsch \& Storey, 2014). 
Although there is a great diversity of approaches in defining the entrepreneurial ecosystem concept, there is some consensus on key elements. Thus, Isenberg (2011) proposed a model consisting of elements grouped into six domains: policy, finance, culture, human capital, infrastructural support, and markets.

Spigel (2017) suggests that EE's elements could be categorized as cultural, social, or material. Another approach is Brown and Mason (2017), who propose a taxonomy featuring four main coordinative aspects of EEs: entrepreneurial actors, entrepreneurial resource providers, entrepreneurial connectors, and entrepreneurial culture. However, some researchers claim that despite the advancement of the existing literature in understanding ecosystems, it is still extremely different to measure them (Theodoraki \& Messeghem, 2017). Others attribute this to the fact that both "inputs" and "outputs" cannot be defined accurately, and at the same time, there are multiple relations between input and output, creating multiple outputs (Audretsch et al., 2018).

\section{Understanding entrepreneurial economies as complex systems}

Entrepreneurship plays a double role: it is the output variable in the geography of entrepreneurship literature, and it is the input variable in the economic growth literature. To complicate matters even more, entrepreneurship and economic growth also affect the inputs of the geography of entrepreneurship, for example, with serial entrepreneurs becoming venture capitalists and creating networks, building on complex systems approaches (Arthur, 2013; Roundy et al., 2017; Stam \& Van de Ven, 2020).

Starting from the model proposed by Brown and Mason (2017), we can see how each pillar (element) of the ecosystem adds to its complexity. An EE perspective is a complex perspective integrating the geography of entrepreneurship and the institutional literature. We build on the integrative model of entrepreneurial ecosystems by Brown and Mason (2017) and Stam and Van de Ven (2020), which includes institutional arrangement and resources, endowment elements that will enable us to construct the EE index, that can be used for an ecosystem independently on its growth orientation or entrepreneurial ambition. This is to say we focus on the four key mechanisms of interdependencies between EE elements suggested by Brown and Mason (2017).

\section{Entrepreneurial actors}

The "prima donna" of EE is the entrepreneur. A person with enough energy and the capacity to imagine and plan things in the future from an independent and leading perspective. Some exceptionally successful entrepreneurs will continue to operate in ecosystems - serial entrepreneurs, angel investors, advisors, or dealmakers. (Spigel \& Harrison, 2018).

Although we admit that successful entrepreneurship will ultimately be a collective affair - an explicit system - as we argue in this study, it is technically correct and necessary to properly understand the key role played by entrepreneurs within the regional or global economy - they are the "seeds" of the EE. Even if entrepreneurs 
choose to exit the market, most of them will remain in the EE. And the system will benefit from the human resource they nurtured and educated.

The very successful, fast-growing start-ups play one positive role. Of course, there aren't many, but they play a major role as models, with fascinating spill-over effects (Brown \& Mason, 2017). “The creation of a country's wealth and dynamism depends upon the competitiveness of its firms and this, in turn, relies fundamentally on the capabilities of its entrepreneurs" (Cuervo et al., 2007: 7). Therefore, we consider the entrepreneurs a main pillar of the EE and will include it in assessing an EE index.

\section{Entrepreneurial connectors}

This structure based on relations facilitates how resources move in an ecosystem so that entrepreneurs can access them (Spigel \& Harrison, 2018). The more entrepreneurs share information and meet, the more they will fulfill the various necessities of the EE panel of clients to the benefit of all. By observing and interacting with others, entrepreneurs also learn new skills, learn how to acquire potential customers and learn how to secure external funding and other resources (Nicotra et al., 2017).

According to Audretsch et al. (2018), ecosystems are inherently based on cooperation and less competition and profit maximization. This is an important statement, which brings both unproductive and productive entrepreneurs to the literature. As Audretsch et al. (2018) fairly mention, profit maximization may not be EE's ambition, but job creation, reduction of poverty, satisfying everyday needs in resources, and sustainability.

Finally, entrepreneurs' resources are often tied to social networks, and hence trust is critical (Spigel \& Harrison, 2018). Social capital and networks effectively act as the arteries circulating the lifeblood of information, ideas, and tacit knowledge enabling ecosystems to function properly (Spigel, 2017).

\section{Entrepreneurial resources providers}

Resource providers are key actors in an EE. When one speaks about resources, it is primarily about financial resources and skills (Belitski et al., 2019). Business angels and venture capitalists not only provide financial capital but knowledge capital (Nicotra et al., 2017), or "knowledge emanating from entrepreneurial firms and incumbents can become a source of knowledge spill-over within each specific context of organization, alliance, industry or region" (Audretsch et al., 2020: 9).

Institutions do not make part of entrepreneurial resources in the ecosystem but can moderate the access to resources and make the region attractive for external funds. Institutions represent the rules and culture of a region (North, 1990) that can be conducive for other resources and support structures to emerge, helping entrepreneurs of all types: physical space, capital, coaching, common services, and networking connections (Nicotra et al., 2017).

Knowledge capital is an important resource for entrepreneurs to grow businesses and compete nationally, regionally, and internationally (Neck et al., 2004). 


\section{Entrepreneurial culture}

It is not easy to change entrepreneurship culture overnight (Levie \& Autio, 2008; Estrin et al., 2013). For example, policy-makers that used to work in different institutional contexts (Aidis et al., 2012), for example, during communist times and in a market economy, may inherit informal institutions from the past (Webb et al., 2019) and continue practicing an informal culture of the previous institutional context. This may significantly affect both policy-makers and entrepreneurs' objective or decision-making, often making them rent-seeking rather than growth-oriented (Méon \& Sekkat, 2005). In the short term, informal, often corrupt practices could have the effect of acting either as a "grease" for the wheels for entrepreneurs (see Belitski et al., 2016; Dreher \& Gassebner, 2013; Shleifer \& Vishny, 2002), but in the long term, it may destroy or impede the growth of the entire EE.

These corrupt practices, which have persisted since the previous regimes in many European countries, still are very much in use by the current policymakers which deeply fraction society, and corrupt media and web, as well as the legal system, make unproductive entrepreneurship activity a new formal law (Webb et al., 2019).

While institutional transformations formally have brought changes to countries, informal mechanisms persist and continue to influence how entrepreneurship is perceived and practiced (Fritsch et al., 2019).

\section{Introducing political entrepreneurship to entrepreneurial ecosystem}

In the Journal of Political Economic article, titled "Entrepreneurship: Productive, Unproductive and Destructive," William Baumol (1990) proposed a theory of entrepreneurship allocation. Desai and Acs (2007) use it to explain why entrepreneurship may not always be associated with higher incomes, innovation, economic growth, and entrepreneurship activity that may not be engaged in activity aimed at increasing wealth, power and prestige (Baumol, 1990). This study proposes the theory of destructive entrepreneurship, which later has gained significant popularity (Weitzel et al., 2010; Desai et al., 2013; Acs et al., 2013; Collins et al., 2016). These studies emphasize that entrepreneurship is not an inherently economically healthy activity and can be allocated among productive, unproductive, and destructive forms. When unproductive and destructive entrepreneurship comes in collaboration with corrupt authorities, political entrepreneurship emerges. Corrupt policymakers may directly or indirectly own or benefit from unproductive entrepreneurship. Corruption can both grease and sand the wheels of business, but in the case of political entrepreneurship, it will only support entrepreneurial activity based on rent-seeking, co-ownership, and bribes (Dreher \& Gassebner, 2013; Sauka \& Welter, 2007; Méon \& Sekkat, 2005).

For entrepreneurial activity in his work Baumol (1990) identifies a crucial role for public policy and government's role in creating conducive conditions for entrepreneurs. He notes that "the prevailing rules that affect the allocation of 
entrepreneurial activity can be observed, described, and, with luck, modified and improved..." (Baumol, 1990: 894).

While the benevolent government would aim to ultimately increase economic development through changes in institutions to promote entrepreneurial activity, in the corrupt government, the goal is rent-seeking and profit maximization for both entrepreneurs and policymakers (Chowdhury et al., 2015). This behavior may increase entrepreneurs' economic wealth but reduce the wealth of the whole society - destructive entrepreneurship.

Simply put, researchers may want to understand and model the "rules of the game" where entrepreneurs and government are intimately working together for rent-seeking and demonstrate the outcome of such behavior for a region. Corrupt government is defined as one that uses the public office for personal benefit (Treisman, 2000) and can manifest itself differently.

Small bribes, which can often be called "attentions," are given to authorities, individuals in power, public leaders, the medical system and even nonfor-profit organizations, police, and teachers. This becomes an informal common law (Aidis et al., 2012). Once corruption becomes deeply embedded in culture, with historical roots, entrepreneurs adjust to the culture and outreach authorities to reduce the effect of burdensome regulation, taxes, and permits (Belitski et al., 2016).

When we talk about political entrepreneurship, it may occur on different scales. From a bribe to speed up the procedures to open a business to governmental contracts, access to resources and construction sites, real estate investments, securing import and export permits, avoiding taxes, and others.

Destructive entrepreneurs may get access to exclusive permits and licenses to use energy, export raw materials, monopoly on import and distribution of rare drugs to the healthcare system. Destructive and unproductive entrepreneurs "backed" by powerful authorities who share business benefits by providing preferences in access to EE resources are referred to as political entrepreneurs.

Political entrepreneurship is a phenomenon of developing and transition countries with weak institutions (North, 1990), the rule of law (Estrin et al., 2013) where the marriage of rent-seeking policymakers and unproductive and destructive entrepreneurs is possible. With an economy with burdensome regulation (Audretsch et al., 2019 b), it may become very hard to impossible to do business profitably without paying informal payments to authorities, avoid high fines and taxes, with the system itself creates conditions to promote such entrepreneurial activity. In an economy where the law changes regularly, the fiscal agents have extended powers over entrepreneurs, and the judicial system is slow and corrupt; political entrepreneurship can become an effective problem-solving tool "greasing the wheels" of entrepreneurs (Belitski et al., 2016).

The Economist observed that "some people have done much better than others, and not all of them by fair means. Communist officials and securocrats who rebranded themselves as democrats had the education and connections to retain power, make money and profit from an insider - dominated privatizations" (The Economist, 2019: 29). Former apparatchiks who rebranded themselves as 
entrepreneurs and have maintained their strong links with authorities, have created a class of "political entrepreneurs" in many East European countries. More specifically they "coercively obtained resources from the state toward processes of production which would not otherwise have taken place" (McCaffrey \& Salerno, 2011: 556) disturbing and exploiting the ecosystem, limiting resources by administrative means for other entrepreneurs. In some instances, political entrepreneurs could use government "intelligence" as an "insurance" for foreign direct investors when investing in their business. This was not possible with other entrepreneurs who had no access to "intelligence insurance" and could not provide as strong insurance to investors in a fragile environment. The way political entrepreneurs become moderators for EE resources to entrepreneurial outcomes of ecosystem, culture and public policy is described in the conceptual framework (Fig. 1).

Figure 1 shows how EE's main pillars (Brown \& Mason, 2017; Stam, 2018) can be transferred into entrepreneurial outcomes and outputs for the region.

We suggest a limited set of factors or elements that affect the prevalence of entrepreneurship in a region. We integrate the insights from the empirical literature on entrepreneurship and institutional economics's geography into Fig. 1, reflecting an entrepreneurial ecosystem framework with four major pillars that are further facilitated by entrepreneurial actors and policy (institutions) (North, 1990). Altogether institutions and entrepreneurial actors (Autio et al., 2014; Audretsch et al., 2019b) face political entrepreneurship, which performs as a filter for entrepreneurial actors. In weak institutions, entrepreneurial actors become unproductive and destructive entrepreneurs once faced with policymakers who become active entrepreneurial actors themselves (Desai et al., 2013; Acs et al., 2013; Collins et al., 2016) (see Fig. 1). This framework with initial four elements provides a compromise between other frameworks with five to fourteen elements (Vedula \& Kim, 2019; Isenberg \& Onyemah, 2016; Acs et al., 2014) in the process of value creation and securing competitive advantage. We build on these frameworks and develop them further by

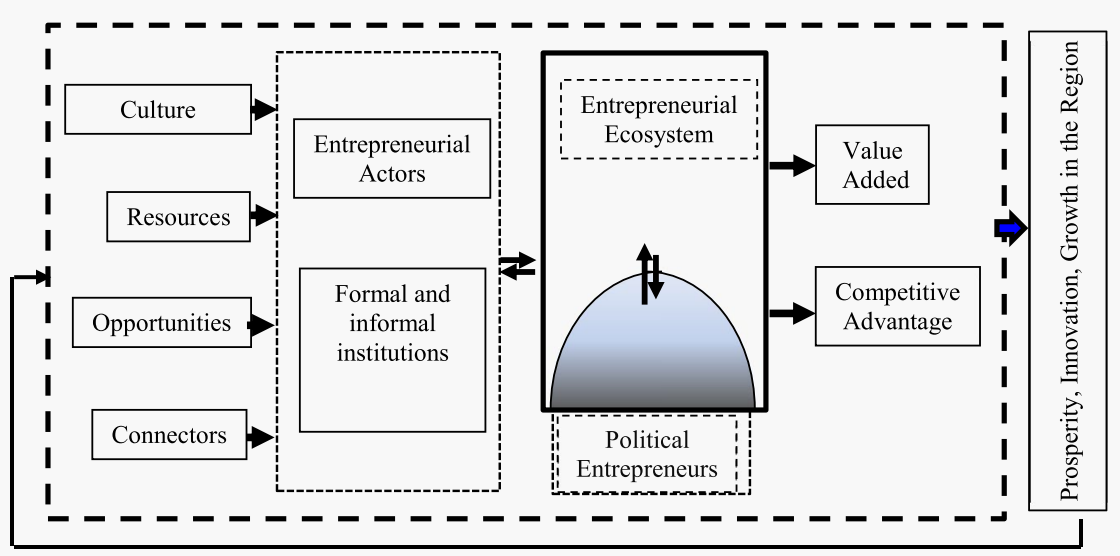

Fig. 1 A conceptual model of political entrepreneurship embedded in entrepreneurial ecosystem 
separating inputs and outputs of the system, providing an academically grounded set of elements, and using empirical indicators more closely reflecting political entrepreneurship as an essential component of EE in countries with weak institutions and the rule of law. This framework contrasts with the Stam (2018) framework for a developed country where formal institutions are strong and the rule of law can be enforced.

Drawing on Desai and Acs (2007) and Desai et al. (2013), we develop three fundamental assumptions how political entrepreneurship can intervene and affect EE: (1) rent-capturing behavior of entrepreneurs and authorities, (2) constant supply of entrepreneurs and their allocation into productive and unproductive ways (3) weak political institutions and high corruption. We hypothesize:

Hypothesis: Political entrepreneurship will moderate stakeholders' perception about the quality of the entrepreneurial ecosystem.

\section{The context of the transition economy}

The World Economic Forum's (WEF) global competitiveness index, defined as the set of institutions, policies, and factors that determine a country's level of productivity, can be considered as an appropriate summary indicator of an entrepreneurial ecosystem. (Kshetri, 2014) The focus of this study is on Romanian city-regions. The World Economic Forum (2019) has ranked Romania as the 51st most competitive country in the world. Countries such as Bulgaria (49th), Hungary (47th), Slovakia (42nd), Poland (37th), and the Czech Republic (32nd) are better ranked than Romania.

According to the World Bank Doing Business Index (2020), Romania ranks in 55th place worldwide, among the last in the EU.

Corruption is a concept often related to Romania. (Iamandi \& Voicu-Dorobantu, 2007). "Corruption is one of the most vexing problems confronting us today, as it inflicts many different layers of economies by distorting incentives and weakening institutions." (Amin \& Soh, 2019, p.2). Romania scored 44 points out of 100 on the 2020 Corruption Perceptions Index reported by Transparency International, again among the last in the EU.

The ranking of Romania - according to these criteria - at the bottom of the EU countries is a complete paradox. The country has enormous potential: it is the 6th country in EU regarding population and the 8th regarding territory (Eurostat, 2020), a complex of natural resources, the second position in EU when we speak about fertile soil areas, perfect climate, high quality of water, excellent crossroads position; it had qualified workforce too (most of it, unfortunately, producing added value for other countries- according to National Statistics Institute (2020) only in 2019, 239,000 Romanians citizens left the country for a period longer than 12 months, following a 13 year trend). What complex factors led to this critical situation? The answer to this question should - and must be a serious challenge to the researcher. A mentality that tolerates systemic corruption - a "Balkanic" mentality, how it is often named - a culture that weakens the institutions and ultimately generates the "political entrepreneurship." 
In the few years after the totalitarian regimes fell in 1990, "apparatchiks" grabbed the most appealing state actives and had access to important financial resources. From this "pole position" primarily acquired, they maintained until today some major profit mechanisms, with political leverage upon institutions and public money, through the corruption of various types and pressure at central and local levels.

While Romania entered European Union in 2007 and was forced to significantly improve its institutional quality, informal institutions such as political entrepreneurship have been preserved. Studies for Romania claim that the quality of institutions is the largest impediment for the prosperity and growth of the country, directly affecting the performance and sustainability of entrepreneurs. Furthermore, in Romania, the EE includes two types of institutions, also known as "two worlds": one protected, fostered by formal institutions, and one exposed, "free to fight" for survival (Ciucan-Rusu \& Szabo, 2013). Sometimes these political entrepreneurs have no employees, no equipment, no industrial facilities, more than often a postcode in some "tax heaven", which is used to exploit local resources in the form of political and destructive entrepreneurship.

The origin of political entrepreneurship is inside the political ecosystem - that was primarily the centralized economy, conducted with iron hands by political apparatus, based on ideological principles with random and weak connections with the objective, statistic laws of economy. A costly experiment in history, but it did exist long enough to induce severe and persistent slippage in mentalities and morale.

To reverse that to natural evolution mechanisms - it is a slow and painful process (the costs are high), but it is yet the best way to progress for humankind.

\section{Data and method}

\section{Interviews and survey description}

To test our conceptual framework, we perform 18 in depth interviews and developed and collected primary data using the online survey of stakeholders (Brown \& Mason, 2017; Godley et al., 2019) in Romania, South-East Europe.

Face-to-face interviews covered all categories of EE stakeholders from the two places (ten from Bucharest and eight from Cluj-Napoca). The interviews provided useful data and nuances complementary to the survey. The profile of the interviewees is presented in the following Table 7 in Appendix.

The questionnaire we sent included 28 questions aiming to capture the variety of EE factors in two major Romanian cities - Bucharest and Cluj-Napoca and 241 responses received with finally 218 used. Please find Table 1 descriptive statistics for the variables. The answers were collected through Google forms during June-September 2019.

\section{Identifying entrepreneurial ecosystem elements}

Regarding the structure of the survey responses, $63.3 \%$ are male, and $36.7 \%$ are female. A proportion of $53.2 \%$ of the respondents are from Bucharest, and the rest 


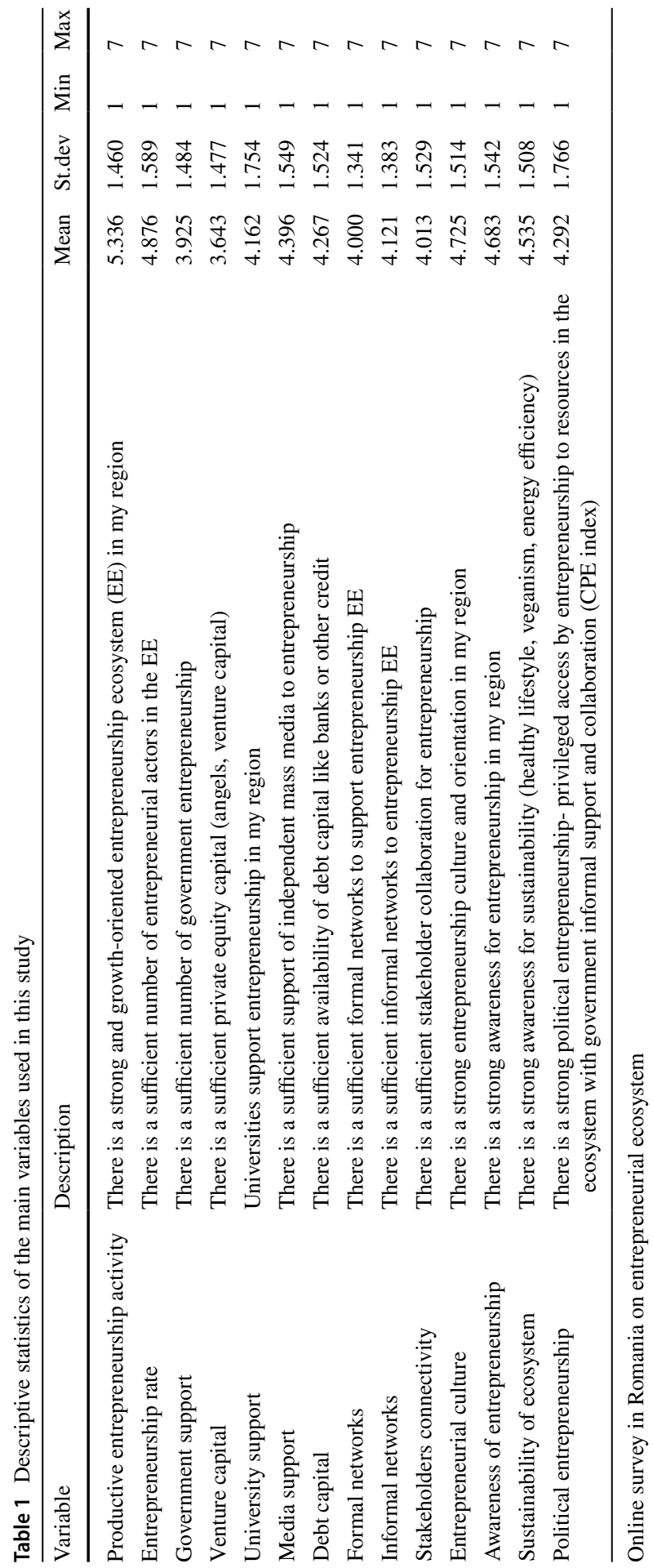


are from Cluj-Napoca, 97.2\% of them having completed higher education. Entrepreneurs constitute $45.4 \%$ of the sample, while $14.7 \%$ were less than 29 years old and $8.6 \%$ were older than 60 .

Our empirical analysis includes several stages.

We start by drawing on Brown and Mason (2017) to combine the characteristics of the ecosystem into four major blocks - indices as an average of the specific components in Table 1, assigning to each variable an equal weight. We had no reason to consider that some characteristics of the ecosystem may contribute differently to ecosystem indices following Stam (2015). We created the Entrepreneurial actor's index (EA) using two variables of Entrepreneurship actors and stakeholders connectivity. We constructed the Entrepreneurial connectors index (ECN) using the variables of formal networks, informal networks, and university support. We constructed the Entrepreneurial resource providers index (ERP) by using the Venture and debt capital, government support. We created the Entrepreneurial culture index (EC) by using the variables of entrepreneurial culture, awareness of entrepreneurship, and Media support. Finally, we also created the Corruption and political entrepreneurship index (CPE) using variables of corruption perception and political entrepreneurship.

Table 2 provides information regarding the reliability of our measurement for each crated index as well as descriptive statistics. All Cronbach's Alpha values are above the minimum threshold of 0.7 , and the composite reliability values have high values in each case.

We then created a quality of ecosystem index (EE) as an average of four indices. This allowed us to increase the variation in the index as well as to include all four elements suggested by Brown and Mason (2017) in one model. The distribution of each index across two regions is in Fig. 2.

Once we developed our indices, the second stage of our empirical analysis demonstrates the differences in perceptions of ecosystem quality and corruption across different respondents. We performed the t-tests to examine the difference in means across three categories the perception about the ecosystem quality and each of its components (1) whether the respondent is an entrepreneur; (2) whether the respondent is from Bucharest or Cluj-Napoca; and (3) whether the entrepreneur is a woman. Table 3 presents the results of the t-test. There are no significant differences between

Table 2 Descriptive statistics for latent variables and reliability of indices

\begin{tabular}{llllllll}
\hline Index & Mean & SD & Median & Min & Max & Cronbach's Alpha & $\begin{array}{l}\text { Composite } \\
\text { reliability } \\
\text { Index }\end{array}$ \\
\hline EA & 4.310 & 1.272 & 4.333 & 1 & 7 & 0.790 & 0.724 \\
ECN & 3.856 & 1.205 & 4.000 & 1 & 7 & 0.860 & 0.836 \\
ERP & 4.124 & 1.223 & 4.333 & 1 & 7 & 0.770 & 0.730 \\
EC & 4.653 & 1.300 & 5.000 & 1 & 7 & 0.851 & 0.828 \\
EE & 4.236 & 1.127 & 4.312 & 1 & 7 & - & - \\
CPE & 4.292 & 1.766 & 4.050 & 1 & 7 & - & - \\
\hline
\end{tabular}

Online survey in Romania on entrepreneurial ecosystem 

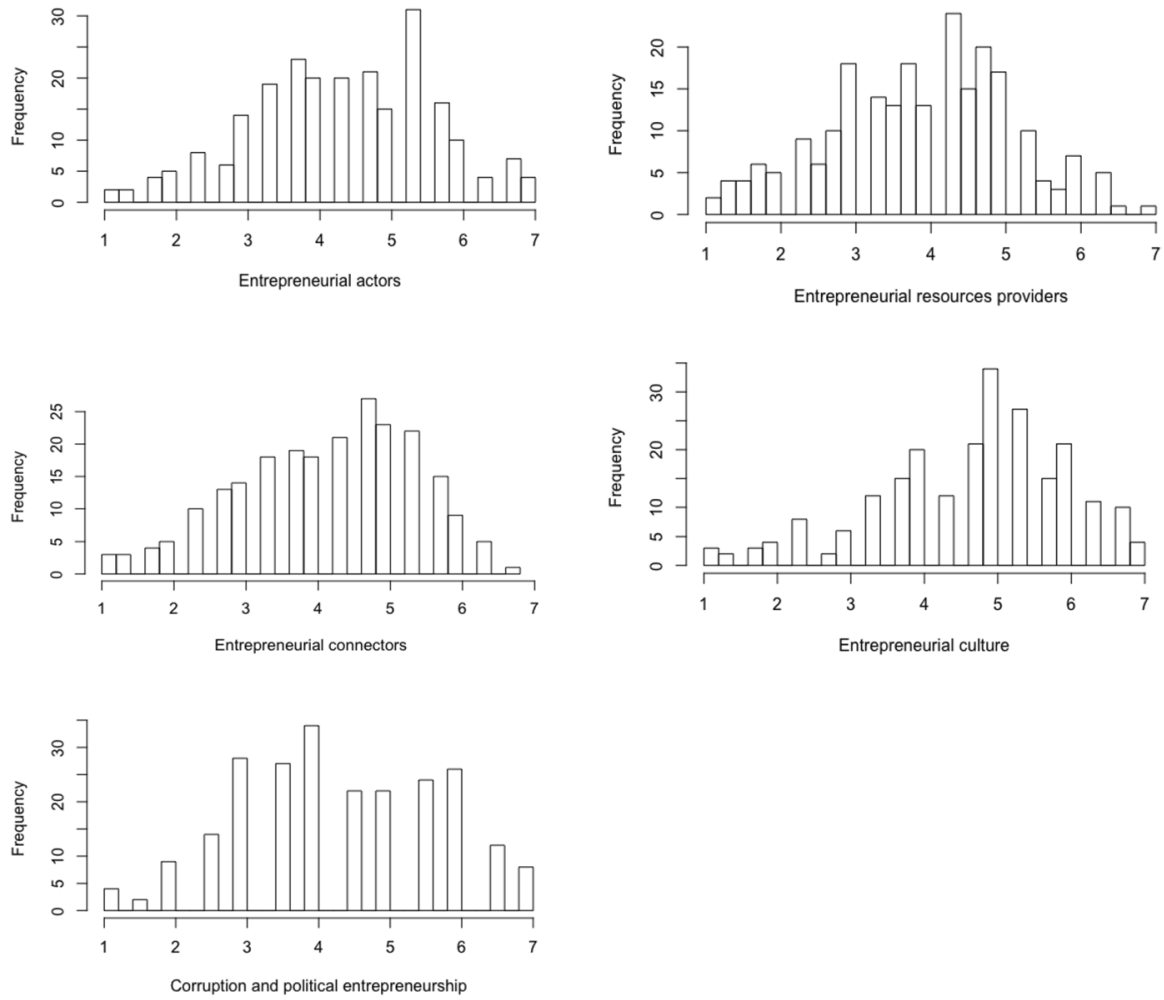

Fig. 2 The distribution of the indices used in the model

Table 3 Difference in means of perception about EE quality and its elements between entrepreneurs and other stakeholders

\begin{tabular}{|c|c|c|c|c|}
\hline \multirow[t]{2}{*}{ Occupation } & \multicolumn{2}{|l|}{ Average value } & \multirow[t]{2}{*}{$P$ - value } & \multirow[t]{2}{*}{ Decision } \\
\hline & Entrepreneur & $\begin{array}{l}\text { Other- } \\
\text { stakeholders }\end{array}$ & & \\
\hline Entrepreneurial actors index (EA) & 4.037 & 4.538 & 0.003 & Reject the null \\
\hline $\begin{array}{l}\text { Entrepreneurial connectors index } \\
(\mathrm{ECN})\end{array}$ & 3.722 & 3.966 & 0.136 & Fail to reject the null \\
\hline $\begin{array}{l}\text { Entrepreneurial resource providers } \\
\text { index (ERP) }\end{array}$ & 3.852 & 4.350 & 0.002 & Reject the null \\
\hline Entrepreneurial culture index (EC) & 4.531 & 4.754 & 0.211 & Fail to reject the null \\
\hline $\begin{array}{l}\text { Corruption and political entrepre- } \\
\text { neurship index (CPE) }\end{array}$ & 4.298 & 4.382 & 0.065 & Fail to reject the null \\
\hline $\begin{array}{l}\text { Entrepreneurial ecosystem quality } \\
\text { index (EE) }\end{array}$ & 4.036 & 4.402 & 0.017 & Reject the null \\
\hline
\end{tabular}

Online survey in Romania on entrepreneurial ecosystem 
stakeholders' perception of each component of the ecosystem by and other EE stakeholders on the quality of entrepreneurial connectors, entrepreneurial culture, and political entrepreneurship - our main variables of interest.

A similar approach explores differences between main EE quality index and other elements between two cities in Romania - Bucharest and Cluj-Napoca (Table 4). Significant differences were found between the two cities in respondents' perception about political entrepreneurship and entrepreneurial culture. Political entrepreneurship was significantly higher in Bucharest - the capital where policymakers are located and can have greater impact on EE.

Likewise, we test potential differences in perception EE quality and its elements between male and female respondents (Table 5). Interestingly that only dimension where the perception does not differ significantly is the perception of corruption and political entrepreneurship. Rest of dimensions the perceptions about EE was significantly different. This is an important finding demonstrates that there is a unity in a society about the degree of political entrepreneurship.

\section{Simulation analysis and measuring entrepreneurial ecosystem}

The third stage of our empirical analysis includes the creation of a dependent variable which will later be used in the estimation, that we call the overall ecosystem index. The overall index adjusts to the perception of respondents in regard to the quality of the ecosystem conditional on the perceived level of political entrepreneurship in the ecosystem. Building on Stam (2018) prior research, we construct the overall ecosystem index by measuring the difference between the perceived quality of the ecosystem (EE) and the penalty component in the function, which is the extent of political entrepreneurship and corruption in a system.

$$
\text { Overall ecosystem index }=\mathrm{EE}-\mathrm{CPE}
$$

This equation proposes that the overall ecosystem index is the difference between the perceived quality of the ecosystem (EE index) and the perceived level of corruption and political entrepreneurship (CPE) by region. To calculate the index, we perform a simulation in which various proportions of CPE are considered in shaping the respondents' overall perception of the ecosystem. Instead of simply subtracting CPE by each respondent, we perform a simulation exercise by generating 100 overall ecosystem indices with each of it varies with the proportion of the perceived corruption and political entrepreneurship. More specifically, the simulation of the overall ecosystem index is explained in the equation below:

$$
\text { Overall ecosystem index }=\mathbf{E E}-(\mathbf{i} / \mathbf{1 0 0}) * \mathbf{C P E}, \mathbf{i}=1, . .100
$$

where $\mathrm{i}$ - is a share of perceptions from 1 to $100 \%$ that accounts for different weights of political entrepreneurship shaping the respondents' perception of the entrepreneurial ecosystem environment.

The fourth stage in our analysis is to explore how the perception of entrepreneurial ecosystem quality, proxied by the overall ecosystem index, depends on the 


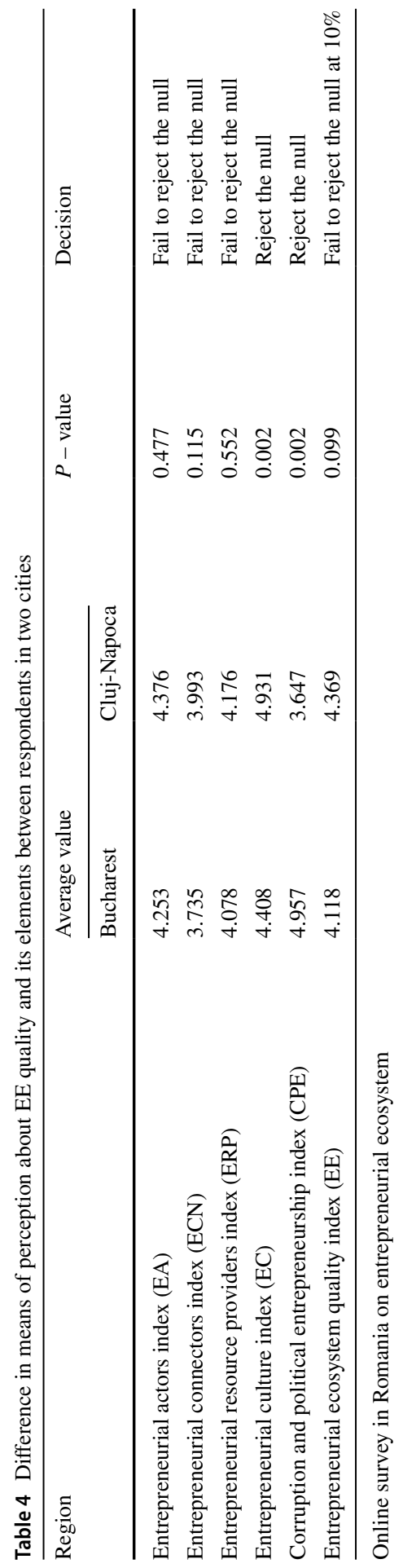


Table 5 Difference in means of perception about EE quality and its elements by gender of respondent

\begin{tabular}{llllll}
\hline \multirow{2}{*}{ Gender } & \multicolumn{2}{l}{ Average value } & $P$-value & Decision \\
& Male & Female & & \\
\hline Entrepreneurial actors index (EA) & 4.174 & 4.546 & 0.03 & Reject the null \\
Entrepreneurial connectors index (ECN) & 3.723 & 4.084 & 0.027 & Reject the null \\
Entrepreneurial resource providers index (ERP) & 3.993 & 4.350 & 0.033 & Reject the null \\
Entrepreneurial culture index (EC) & 4.519 & 4.883 & 0.037 & Reject the null \\
Corruption and political entrepreneurship index & 4.391 & 4.263 & 0.526 & Fail to reject the null \\
$\quad$ (CPE) & & & & \\
Entrepreneurial ecosystem quality index (EE) & 4.102 & 4.466 & 0.017 & Reject the null \\
\hline
\end{tabular}

Source: Online survey in Romania on entrepreneurial ecosystem

respondents' perception of political entrepreneurship and corruption in the ecosystem and whether the relationship varies by our main explanatory variables, which may define the perception of EE quality - gender, occupation category (entrepreneur vs. other), the sustainable orientation of business, region and productive entrepreneurship. Having simulated 100 models, we produced the histograms (Appendix Fig. 5) and plotted them (Fig. 3). The results demonstrate the coefficient's size in the relationship between political entrepreneurship and the overall ecosystem quality by five respondents' characteristics (see Fig. 3). We also illustrate the relationship between ecosystem quality and the perception of the extent of political entrepreneurship across different respondent's characteristics in Fig. 4.

One can notice that the main differences in the ecosystem quality conditional on the perceptions of political entrepreneurship vary by region but they change significantly more compared to the rest of the factors.

\section{Model}

To test our hypotheses, we use ordinary least square (OLS) estimation. We follow Baltagi (2008) who considered the regression model to capture the effects within the cross-sectional data given. The cross-sectional OLS regression does not allow

Fig. 3 The relationship between the perception of ecosystem quality and the degree of political entrepreneurship by five respondents characteristics using 100 Monte-Carlo simulations

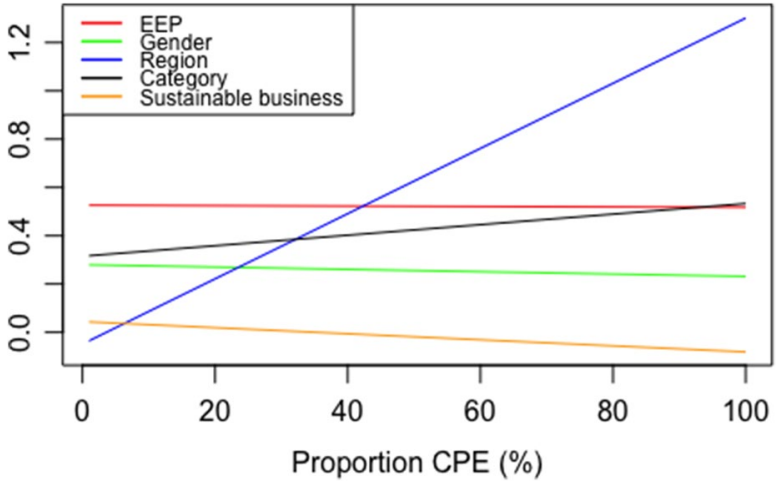




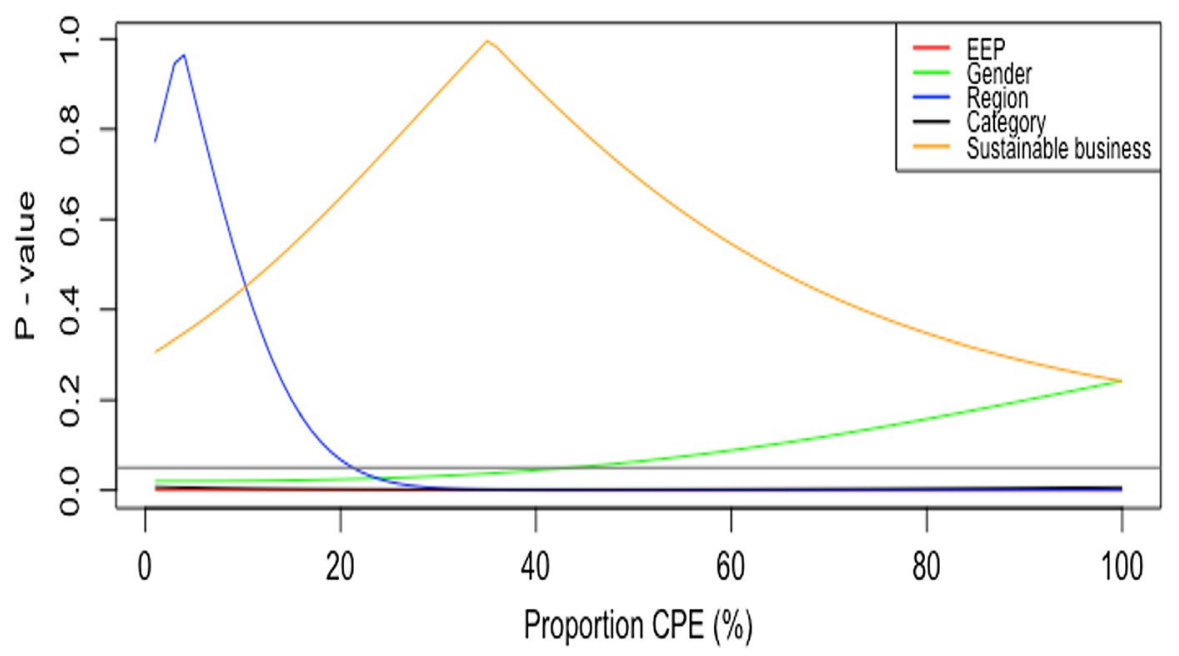

Fig. 4 changes in the relationship between the overall ecosystem index and explanatory variables at different level of CPE ( $p-$ values are reported). Note: solid line for 0.05 is equal to the significance rate of $p=0.05 \%$. own calculation.

for unobserved heterogeneity across cities and time and has its drawbacks related to inferences and establishing the causal relationship. The following model was estimated:

$$
y_{i}=f\left(\beta x_{i}, \mu_{i t}\right) \mathrm{i}=1, \ldots, \mathrm{N}
$$

where $\mathrm{y}_{i}$ is an overall ecosystem index calculated in eq. (2) following drawing on the theoretical approach of Stam (2015), with adjustment for political entrepreneurship in each city $i$ in 2018-2019. $\beta$ and $\Theta$ are parameters to be estimated, $\mathrm{x}_{i t}$ is a vector of independent explanatory variables related to testing our hypothesis such as are respondents' perception regarding the entrepreneurial ecosystem quality proxied by productive entrepreneurship, gender, occupation, region and whether the respondents perceive businesses as sustainable. at time $t$ by city $i$.

\section{Results}

\section{Quantitative results of the survey}

Table 6 below presents the results of a regression analysis (3). Columns 1 and 2 present illustrate the productive entrepreneurship activity (EEP) effect. As one would expect, an increase in productive entrepreneurship increases the overall quality of the ecosystem, and this demonstrates that the index was calculated correctly. The coefficient of productive entrepreneurship activity (EEP) is positive and significant, confirming that direct effect on entrepreneurial ecosystems. The goodness of fit of specification 1 with an R-square of 0.465 means that $46.58 \%$ of the variance 
Table 6 OLS regression results. DV: Overall ecosystem index

\begin{tabular}{|c|c|c|}
\hline $\begin{array}{l}\text { Model } \\
\text { Specifications }\end{array}$ & $\begin{array}{l}\text { EE index } \\
\text { (1) }\end{array}$ & $\begin{array}{l}\text { EE index } \\
\text { (2) }\end{array}$ \\
\hline Constant & $\begin{array}{l}-0.919 * * \\
(0.002)\end{array}$ & $\begin{array}{l}3.201 * * * \\
(p<0.001)\end{array}$ \\
\hline $\begin{array}{l}\text { Productive entrepreneurship } \\
\text { activity (EEP) }\end{array}$ & $\begin{array}{l}0.526 * * * \\
(0.001)\end{array}$ & - \\
\hline $\begin{array}{l}\text { Male } \\
\text { Female }\end{array}$ & $\begin{array}{l}\text { Reference } \\
0.279 * \\
(0.020)\end{array}$ & $\begin{array}{l}\text { Reference } \\
0.269 \\
(0.087)\end{array}$ \\
\hline $\begin{array}{l}\text { Bucharest city } \\
\text { Cluj-Napoca city }\end{array}$ & $\begin{array}{l}\text { Reference } \\
-0.049 \\
(0.688)\end{array}$ & $\begin{array}{l}\text { Reference } \\
0.326 * \\
(0.035)\end{array}$ \\
\hline $\begin{array}{l}\text { Entrepreneur } \\
\text { Other stakeholder }\end{array}$ & $\begin{array}{l}\text { Reference } \\
0.315 * * \\
(0.008)\end{array}$ & $\begin{array}{l}\text { Reference } \\
0.396 * \\
(0.011)\end{array}$ \\
\hline Equity capital & $\begin{array}{l}0.098 * * * \\
(0.03)\end{array}$ & $\begin{array}{l}-0.043 \\
(0.07)\end{array}$ \\
\hline Debt capital & $\begin{array}{l}0.112^{* * * *} \\
(0.02)\end{array}$ & $\begin{array}{l}0.252 * * * \\
(0.07)\end{array}$ \\
\hline Formal networks & $\begin{array}{l}0.015 \\
(0.03)\end{array}$ & $\begin{array}{l}0.0175 \\
(0.09)\end{array}$ \\
\hline Informal networks & $\begin{array}{l}0.076^{* * * *} \\
(0.03)\end{array}$ & $\begin{array}{l}0.085 * * * \\
(0.03)\end{array}$ \\
\hline Culture & $\begin{array}{l}0.222 * * * \\
(0.03)\end{array}$ & $\begin{array}{l}0.291 * * * \\
(0.08)\end{array}$ \\
\hline $\begin{array}{l}\text { Sustainable ecosystem Yes } \\
\text { Sustainable ecosystem No }\end{array}$ & $\begin{array}{l}\text { Reference } \\
0.044 \\
(0.293)\end{array}$ & $\begin{array}{l}\text { Reference } \\
0.123 * \\
(0.024)\end{array}$ \\
\hline R2/Adjusted R2 & $46.58 \% / 45.32 \%$ & $18.4 \%$ / $6.68 \%$ \\
\hline Number of observations & 218 & 218 \\
\hline RMSE & 2.63 & 3.05 \\
\hline
\end{tabular}

in the overall ecosystem index could be explained with the variables in the model. In the second specification, once we take out control for productive entrepreneurship activity in the ecosystem and leave the rest of the explanatory variables, the explanatory power of the model decreases to $18.4 \%$. Based on this sensitivity analysis, we conclude that productive entrepreneurship (EEP) in the ecosystem has a significant contribution, up to $38 \%$ of the variation of the perceived entrepreneurial ecosystem quality.

Finally, Fig. 4 presents the $p$ - values attached to each explanatory variable when estimating the regression model (3) and dependent on the proportion accounted for $\mathrm{CPE}$. The results demonstrate that productive entrepreneurship in the ecosystem (EEP) is positively associated with the overall quality of $\operatorname{EE~}(\beta=0.526, p<0.05)$ at every level of political entrepreneurship. Regional effects become stronger once the perceived level of entrepreneurship is greater than $25 \%$. The gender effects 
become insignificant with an increase in political entrepreneurship. While we find that changes in the perception of political entrepreneurship (CPE) in a city moderate other ecosystem characteristics such as gender and region in their relationship to productive entrepreneurship, it does not change the extent that EEP affects the overall ecosystem quality. Our main variable of interest the EEP remains significant at any level of political entrepreneurship and corruption index (CPE).

Our results demonstrate that $\mathrm{CPE}$ is institutionalized in both regions (CuervoCazurra, 2006) as changes in CPE do not affect the extent to which EEP can change the overall ecosystem index. This is harmful to ecosystem quality as the main determinant of it - EEP does not contribute to ecosystem quality as corruption level may change. When the proportion of corruption and political entrepreneurship increases, the difference between non-entrepreneurs and entrepreneurs' perception of the ecosystem increases. The opposite tendency applies to region. When CPE increases the respondents from Cluj-Napoca tend to perceive a better EE than the respondents from Bucharest.

\section{Interview results}

Our interviewees shared that they are they often feel poorly rewarded for their entrepreneurial effort in Romanian EE. This is associated with several factors: high doing business risks, uncertain future, so an entrepreneur is reluctant to open business and talk to community about it. I6 comments

"There were many projects with EU money destined to educate entrepreneurial spirit and to create an entrepreneurial culture. In the last years, the population began to understand the important role of entrepreneurs for society. Tolerance of failure is still a problem in Romania. It is still a "disaster" if you fail...” (Interviewee 6)

A sensible difference in perception between the entrepreneurs and the rest of stakeholders should be noted, when we consider availability of resources to entrepreneurs.

I1 explains “Local and national government unfortunately doesn't help enough; there are some governmental programmes, but the bureaucracy is huge and usually money comes late, and so there are hidden costs that perturbed the initial business plans. There are incubators, some of them are functioning well, part of them were created because it was a 'must'.

I12 focuses on specific resource providers: "Apart the main money providers which are the banks, some others: e.g. business angels and venture capital are new comers on the scene, but they are not yet at a critical mass."

A better perception of EE in Cluj-Napoca than in Bucharest seems surprising, Cluj is a newcomer in comparison with Bucharest. But concerning traditions, education, working attitude, that's another story. Cluj region have been 700 years in close contact with the German culture regarding production and people: discipline and rigour oriented, but liberal. The individual should look diligently for his own 
prosperity and his family, for which he is the most responsible. This particular type of culture believes in community and in things well done. There are notable differences in the perception of the corruption levels. There is the following explanation which comes to mind. We observe at Cluj a better perception regarding the EE. We believe at this point that the respondents are subconsciously influenced by trends and the growth gradient of the local economy and the persistence of entrepreneurs (Fritsch et al., 2019). Cluj is a relatively newcomer at the top, but the last years were impressive: to mention only the real-estate parameters, who would think that Cluj will reach the Bucharest quotations for the built square meter? The differences concerning the resources providers - not so important this time, could be explained geographically. Many resources are coming from the European Union, and Cluj-Napoca is better placed.

And, significantly in our opinion, the local administrative leaders, properly understanding the environment, gradually exceeded the miserable political swamps, bureaucratic and greedy, to a more human and growth-oriented attitude; they are now an established brand in the country. These stakeholders explain.

I13 states that "Public administration in Cluj-Napoca is welcoming and encouraging initiatives; and the regulatory environment is good, much better than elsewhere in Romania, especially in last 3-5 years under the new mayor, when political entrepreneurship starts disappearing in a city.

I14 further adds "Local government understands that success and well-being of community are not dependent on local government alone, but also external finance and free competition without corrupt ties would be a facilitator of the ecosystem.

I18 was harsh about the phenomenon in the country: "Late totalitarian system is to blame - parasites before, parasites now, and they move from one generation to the next in the same logic. This troubles me.... They "poison" business environment limiting natural growth for other more competitive entrepreneurs and making privileged share the "pie". But even worse, their presence is generating corruption in the whole system - because corruption is like a virus: it exists latent in nature (in this case "human nature") and when it meets favourable conditions it infects the body in no time, crippling badly an otherwise healthy and promising EE". I18 continues "There are some notable exceptions in the northern territories of the continent, who have succeeded to build an efficient immune system".

Finally, I16 posits: "In terms of the policy environment, from my observation the mayor is open. He is open to dialogue, open to listening. He says he hates political entrepreneurship - people believe him. You could say that he has time on his side: Cluj is booming. The infrastructure is being improved rapidly and while corrupt practices still persist, new market opportunities take over".

The differences in attitudes towards sustainability of EE between the two regions are understandable. The industries in Cluj-Napoca are relatively new and 
technologically more sophisticated. They attracted a young and educated labour force, with a different mentality and perception of the environment and nature. Plus, as two different participants noted:

I17 comments "There are business angel financing only eco-friendly business, and something more substantial companies would need to liaise with authorities”. This demonstrates that political entrepreneurship becomes an issue, once the returns to the project or the scope and size of the business project increases. I9 further adds "We have start-ups, developed start-ups, mature companies that want to get involved in community projects, but we need "ok" by authorities. These are unlikely to give us a green light unless they directly or indirectly benefit from the project".

I2 further comments "This was not the case a few years ago in our city. You would need to know someone from city administration to participate in a competition or win a grant. Moreover these policy-makers had their own companies. Public administration is now also active on international platforms, events, but not without the self-benefit.

I15 also posits that "One of our biggest challenges to understand the degree of political entrepreneurship is the absence of data. Things are moving fast and hence it is hard to keep up. We encourage the philosophy of "make meaning, not money".

I18 also mentions some traits of a political entrepreneur: "About the typical actor of a post-communist country - the political entrepreneur - they envisage and envelop business opportunities with considerable added - value, even temporary; or to benefit from a temporary monopoly situation. They have usually a cynical attitude towards business: they do not "attach" themselves to a particular field-their dream is to accumulate, no matter how, fundamentally he is a "fake".

First, we noticed through the subjects`answers a common opinion that Romania is still in a transition paradigm, oriented to a better understanding and a proper culture on entrepreneurship by the society as a whole, but still marked by sequels of ideological origin, like the embedded fear and shame of failure.

Second, some interviewees observed the excessive bureaucracy and the perpetual habit of avoiding taking responsibility. The subjects also underline the scarcity of financial resources providers and the high costs of money.

Third, the perceived differences between the two regions are substantial. The respondents attributed the spectacular evolution of the Cluj EE to the town's quality of local administration. Interestingly, that regional cities such as Cluj are less corrupt. However, we started to understand that communities are protective in small cities and can "cover-up" political entrepreneurship, while in Bucharest -large city communities are diverse and corruption becomes more visible.

Fourth, our interview findings also call for more analysis on gender perspective. 
The literature is practically unanimous in presenting statistics that show that women face more constraints than a business man (Fairlie \& Robb, 2009), having lower access to resources and institutional support (Coleman, 2002; Van der Zwan et al., 2012). In the entrepreneurial process, there is a difference between intentions and action (Gieure et al., 2020).

In summary, the respondents appreciate rather positively the evolution trends of the systems towards mature and productive EE's, open to a European free-market mentality. However, the progress is (too) slow, nonlinear, with setbacks, still seriously threatened by corruption, lack of competence and the lethal interference of the political factor.

\section{Discussion and conclusions}

Our study of political entrepreneurship's value-added is that it provides a framework - a missing link between institutions and entrepreneurship literature explaining the destructive nature of political entrepreneurship with its gender and regional aspects. Of course, political entrepreneurs are an economic reality of developing and transition economies where formal institutions and culture of corruption and communities are deeply embedded into developmental policies and laws. We demonstrated that political entrepreneurship and corruption had been institutionalized (CuervoCazurra, 2006).

While the objective of EEs in developed economies (Stam, 2015, 2018; Stam \& Van de Ven, 2020) is productive and growth-oriented entrepreneurship activity, regional economic development (Audretsch \& Belitski, 2021), this study argues that these objectives cannot be taken for granted in developing and transition countries. For these countries, the gap between productive and unproductive entrepreneurship (Desai \& Acs, 2007) in the regional entrepreneurial ecosystems is still large. This gap is mainly caused by the market uncertainty and the perception of political entrepreneurship and corruption that sands the wheels of business in transition economies. Productive and growth-oriented entrepreneurs who cannot secure authorities' support or have no funds to pay bribes and penetrate the political entrepreneurship filter may not continue with the earlystage activity and will be forced into the semi-formal economy or market exit. There also remains a significant number of business registrations registered as "one-day firms" to participate in corrupt practices and money laundering (Belitski et al., 2016).

The important policy implications for transition countries are developed.

First, acknowledging the problem at the regional and national and European levels that "political" entrepreneurship is a hidden form of destructive entrepreneurship (Baumol, 1990) with strong privileged access to resources and markets in the region benefits rent-seeking authorities. It is important to uncover the ultimate goal of "political" entrepreneurship, which is less likely long-term growth-oriented 
business, as time in the office is limited and the rent-seeking opportunities are limited as well.

Second, institutional trust and transparency in transition economies, particularly to court systems to uncover and make unproductive activities by political entrepreneurs more visible and put a peer-pressure by electorate and communities. While rent-seeking behavior only aims at profit maximization for a limited number of entrepreneurial actors and connectors (Brown \& Mason, 2017), this form of entrepreneurship distorts markets.

Third, while political entrepreneurs' objective is to reallocate resources and prevent market entry by other early-stage entrepreneurs in the ecosystem, lower regulatory burden and transparency of grant applications and public procurement is a must.

Fourth, we ask: "How sustainable is political entrepreneurship" to transition economy? The answer it is not, as it impedes economic development and free-market competition making customers pay more for the products and services. Control over public procurement, publishing contracts, and grants in the open press and platforms could become the first step to providing equal access to information for entrepreneurs connected to authorities and other EE stakeholders, including independent media.

Fifth, long-term political entrepreneurship is not sustainable and can be limited to the term in office with international pressure and market competition needed to be increased. It is easier for countries within the European Union to achieve through the existing mechanisms of audit and standards of data disclosure enforced by the European Commission. For non-EU countries, such as Serbia, Montenegro, Albania, Ukraine, any international pressure, including by the European Commission, is limited. This may be conducive to further persistence of political entrepreneurship in the region. Improving the quality of institutions and law enforcement (Fritsch et al., 2019) may be important to minimize political entrepreneurship's negative effect on productive entrepreneurship in the ecosystem.

The policy can change overnight, while informal institutions that support political entrepreneurship may not. This is important to understand for entrepreneurs who plan to start a business in developing and transition economies. Creating social ties (Bordeaux and Nikolaev, 2019) may be necessary for market entry and competition in economies with weak institutions. The culture of a region has changed since many countries joined the European Union and became more open to international entrepreneurship, which pushes for higher quality, disclosure, and law rule.

Lastly, government policies are important to pursue productive goals of ecosystems (Stam, 2018) and understanding the mechanisms we uncovered in this study, such as stakeholder type, productive entrepreneurship, the role of regional location, and governance that can become a role model for other regions to fight political entrepreneurship. The example of Cluj city-region is appealing. Local and national governments would need to adopt a place-based approach when fighting political 
entrepreneurship. This study further calls for action by local policymakers and entrepreneurial actors to collaborate on transparency to increase institutional trust that may impede EE quality.

Implications for the foreign investors include a need to be aware that success in the market may be related to the strength of the relationship with authorities, but formal institutions can be used more effectively to enforce the rule of law, particularly in countries within the European Union.

The situation may be very particular in countries where post-communist "nomenklatura" still persists and is not aligned with entrepreneurial activity, such countries in Eastern and southeast Europe. In these countries of Europe, bureaucrats have maintained the informal institutions' system and social ties and implement it for an ecosystem for rent-seeking. Further research should contribute to the time scale of the phenomenon and whether this problem is a short or long-term issue, again more longitudinal data before joining the EU and after is important to further unpack it. Further data may also be used to calculate the costs and benefits of political entrepreneurship in developing and transition economies, to understand the damage corruption and political entrepreneurs puts on EE.

\section{Limitations and further research}

Although this study has several significant limitations, such as cross-sectional data and a limited number of experts and interviewees, it allowed for mixed methods to be used to demonstrate how determinants of EE can lead to competitive advantage and higher EE quality. Further studies with longitudinal data on changes in attitudes towards political entrepreneurship and EE's quality should follow. That would allow us to test our conceptual framework of political entrepreneurship as one of EE's outcomes and a moderator of EE inputs and outputs.

Further research effort needs to engage with the mechanisms and best practices on dealing with political entrepreneurship most effectively. Further research on entrepreneurial actors is needed who are corrupt to demonstrate its harmful role for society and economy as corruption is very, very contagious. So, instead of curing our weak institutions, this "virus," we may contaminate other ecosystems in the European Union, particularly with well-developed social ties and post-communist past.

In order to make more EE stakeholders aware of how dangerous political entrepreneurship is, the task for scholars, entrepreneurs, and policymakers. More research is needed on understanding the artificial mechanisms that impede market tools of doing business and resolving problems by "greasing the wheels" of authorities. The economic impact still requires further investigation.

Further research will directly bring the role of formal institutions that need to ensure the rule of law in a country and how it changes, greasing authorities and entrepreneurs' wheels. 


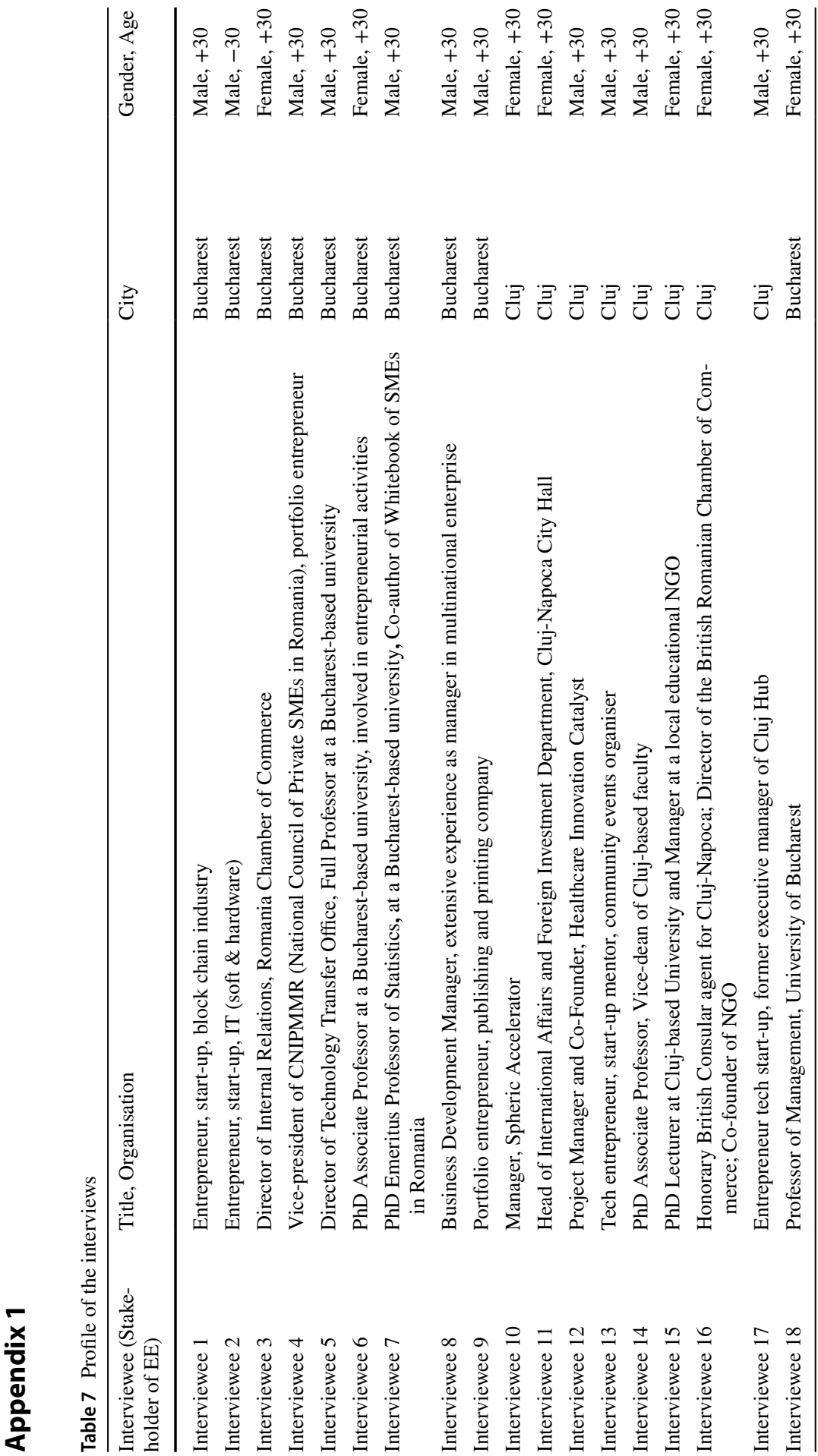




\section{Appendix 2}
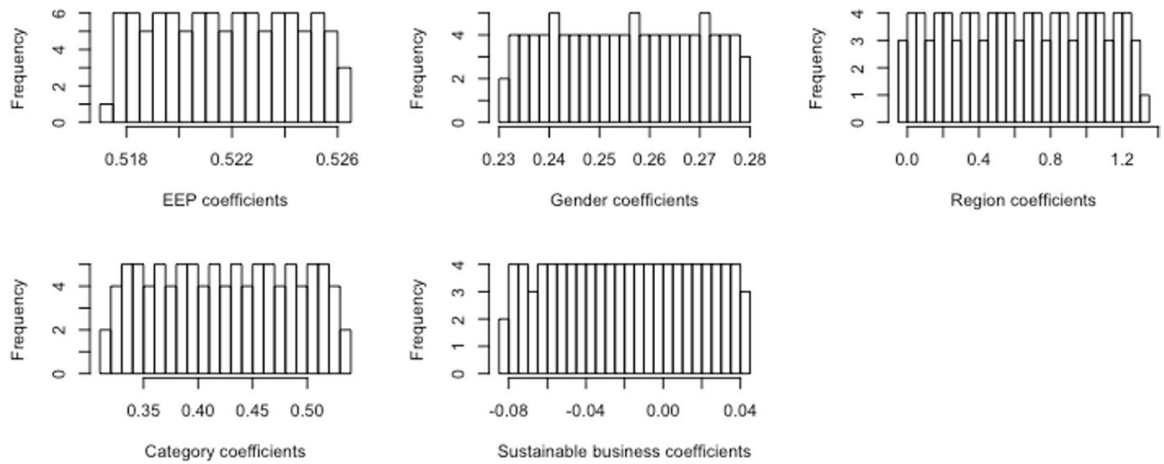

Fig. 5 Estimated coefficients of 100 regression models - histograms

Supplementary Information The online version contains supplementary material available at https://doi. org/10.1007/s11365-021-00750-w.

Open Access This article is licensed under a Creative Commons Attribution 4.0 International License, which permits use, sharing, adaptation, distribution and reproduction in any medium or format, as long as you give appropriate credit to the original author(s) and the source, provide a link to the Creative Commons licence, and indicate if changes were made. The images or other third party material in this article are included in the article's Creative Commons licence, unless indicated otherwise in a credit line to the material. If material is not included in the article's Creative Commons licence and your intended use is not permitted by statutory regulation or exceeds the permitted use, you will need to obtain permission directly from the copyright holder. To view a copy of this licence, visit http://creativecommons.org/licen ses/by/4.0/.

\section{References}

Acs, Z. J., Boardman, M. C., \& McNeely, C. L. (2013). The social value of productive entrepreneurship. Small Business Economics, 40(3), 785-796.

Acs, Z. J., Autio, E., \& Szerb, L. (2014). National systems of entrepreneurship: Measurement issues and policy implications. Research Policy, 43(3), 476-494.

Acs, Z. J., Stam, E., Audretsch, D. B., \& O'Connor, A. (2017). The lineages of the entrepreneurial ecosystem approach. Small Business Economics, 49(1), 1-10.

Aidis, R., Estrin, S., \& Mickiewicz, T. (2012). Size matters: Entrepreneurial entry and government. Small Business Economics, 39(1), 119-139.

Amin, M., \& Soh, Y. (2019). Corruption and Country Size Evidence Using Firm-Level Survey Data, Policy Research Working Paper 8864, World Bank Group.

Arthur, W. B. (2013). Complexity economics. Oxford University Press.

Audretsch, D. B., \& Belitski, M. (2017). Entrepreneurial ecosystems in cities: Establishing the framework conditions. The Journal of Technology Transfer, 42(5), 1030-1051. 
Audretsch, D. B., \& Belitski, M. (2021). Towards an entrepreneurial ecosystem typology for regional economic development: The role of creative class and entrepreneurship. Regional Studies, 55(4), $735-756$.

Audretsch, D. B., \& Lehman, E. (2005). Does the knowledge spillover theory of entrepreneurship hold for regions? Research Policy, 34(8), 1191-1202.

Audretsch, D. B., Obschonka, M., Gosling, S. D., \& Potter, J. (2018). A new perspective on entrepreneurial regions: Linking cultural identity with latent and manifest entrepreneurship. Small Business Economics, 48(3), 681-697.

Audretsch, D. B., Cunningham, J. A., Kuratko, D. F., Lehmann, E. E., \& Menter, M. (2019a). Entrepreneurial ecosystems: Economic, technological and societal impacts. The Journal of Technology Transfer, 44(2), 313-325.

Audretsch, D. B., Belitski, M., \& Desai, S. (2019b). National business regulations and city entrepreneurship in Europe: A multilevel nested analysis. Entrepreneurship Theory and Practice, 43(6), 1148-1165.

Audretsch, D. B., Belitski, M., Caiazza, R., \& Lehman, E. E. (2020). Knowledge management and entrepreneurship. International Entrepreneurship and Management Journal, 16, 373-385.

Autio, E., Kenney, M., Mustar, P., Siegel, D., \& Wright, M. (2014). Entrepreneurial innovation: The importance of context. Research Policy, 43(7), 1097-1108.

Baltagi, B. (2008). Econometric analysis of panel data. John Wiley \& Sons.

Baumol, W. J. (1990). Entrepreneurship, productive, unproductive, and destructive. Journal of Political Economy, 98(5), 893-921.

Belitski, M., Chowdhury, F., \& Desai, S. (2016). Taxes, corruption, and entry. Small Business Economics, 47(1), 201-216.

Belitski, M., Caiazza, R., \& Rodionova, Y. (2019). Investment in training and skills for innovation in entrepreneurial start-ups and incumbents: Evidence from the United Kingdom. International Entrepreneurship and Management Journal, 16(2), 617-640.

Bogers, M., Sims, J., \& West, J. (2019). What is an ecosystem? Incorporating 25 years of ecosystem research. Academy of Management Proceedings, 1(11080).

Bosma, N., \& Sternberg, R. (2014). Entrepreneurship as an urban event? Empirical evidence from European cities. Regional Studies, 48(6), 1016-1033.

Bosma, N., Sanders, M., \& Stam, E. (2018). Institutions, entrepreneurship, and economic growth in Europe. Small Business Economics, 51(2), 483-499.

Brown, R., \& Mason, C. (2017). Looking inside the spiky bits: A critical review and conceptualisation of entrepreneurial ecosystems. Small Business Economics, 49(1), 11-30.

Brown, R., \& Mawson, S. (2019). Entrepreneurial ecosystems and public policy in action: A critique of the latest industrial policy blockbuster. Cambridge Journal of Regions, Economy and Society, 12(3), 347-368.

Bruns, K., Bosma, N., Sanders, M., \& Schramm, M. (2017). Searching for the existence of entrepreneurial ecosystems: A regional cross-section growth regression approach. Small Business Economics, 49(1), 31-54.

Chowdhury, F., Audretsch, D. B., \& Belitski, M. (2015). Does corruption matter for international entrepreneurship? International Entrepreneurship and Management Journal, 11(4), 959-980.

Ciucan-Rusu, L., \& Szabo, Z. K. (2013). The pyramid of entrepreneurship in Romania: Towards new approach. In B. Ramadani \& C. Schneider (Eds.), Entrepreneurship in the Balkans. (pp.269-292). Springer.

Cohen, B. (2006). Sustainable valley entrepreneurial ecosystems. Business Strategy and the Environment, 15(1), 1-14.

Coleman, S. (2002). Constraints faced by women small business owners: Evidence from the data. Journal of Developmental Entrepreneurship, 7(2), 151-174.

Collins, J. D., McMullen, J. S., \& Reutzel, C. R. (2016). Distributive justice, corruption, and entrepreneurial behavior. Small Business Economics, 47(4), 981-1006.

Content, J., Bosma, N., Jordaan, J., \& Sanders, M. (2019). Entrepreneurial ecosystems, entrepreneurial activity and economic growth: New evidence from European regions. Regional Studies, 54(8), 1007-1019.

Cuervo, A., Ribeiro, D. \& Roig, S. (2007). Entrepreneurship - concepts, theory and perspective. Introduction. Springer.

Cuervo-Cazurra, A. (2006). Who cares about corruption? Journal of International Business Studies, 37(6), 807-822. 
Desai, S., \& Acs, Z. J. (2007). A theory of destructive entrepreneurship. Jena economic research paper, no. 2007-085.

Desai, S., Acs, Z. J., \& Weitzel, U. (2013). A model of destructive entrepreneurship: Insight for conflict and postconflict recovery. Journal of Conflict Resolution, 57(1), 20-40.

Dreher, A., \& Gassebner, M. (2013). Greasing the wheels? The impact of regulations and corruption on firm entry. Public Choice, 155(3-4), 413-432.

Estrin, S., Korosteleva, J., \& Mickiewicz, T. (2013). Which institutions encourage entrepreneurial growth aspirations? Journal of Business Venturing, 28, 564-580.

Eurostat (2020). Population projections in the EU, Retrieved December 27, 2020, from https://ec.europa. eu/eurostat/web/population-demography-migration-projections/publications.

Fairlie, R. W., \& Robb, A. M. (2009). Gender differences in business performance: Evidence from the characteristics of business owners survey. Small Business Economics, 33(4), 375-395.

Fan, P., Urs, N., \& Hamlin, R. E. (2019). Rising innovative city-regions in a transitional economy: A case study of ICT industry in Cluj-Napoca, Romania. Technology in Society, 58, 101-139.

Feld, B. (2012). Startup communities: Building an entrepreneurial ecosystem in your city. Wiley.

Feldman, M. P. (2014). The character of innovative places: Entrepreneurial strategy, economic development, and prosperity. Small Business Economics, 43(1), 9-20.

Fritsch, M., \& Storey, D. J. (2014). Entrepreneurship in a regional context: Historical roots, recent developments and future challenges. Regional Studies, 48(6), 939-954.

Fritsch, M., Sorgner, A., Wyrwich, M., \& Zazdravnykh, E. (2019). Historical shocks and persistence of economic activity: Evidence on self-employment from a unique natural experiment. Regional Studies, 53(6), 790-802.

Gieure, C., Benavides-Espinosa, M., \& Roig, S. (2020). The entrepreneurial process: The link between intentions and behavior. Journal of Business Research, 112(C), 541-448.

Godley, A., Morawetz, N., \& Soga, L. (2019). The complementarity perspective to the entrepreneurial ecosystem taxonomy. Small Business Economics. https://doi.org/10.1007/s11187-019-00197-y.

Iamandi, I.-E., \& Voicu-Dorobantu, R. (2007). Coruptia - un risc pentru Romania in Uniunea Europeana. Romanian Journal of Economic Forecasting, 10(24), 15-27.

Iansiti, M., \& Levien, R. (2004). The keystone advantage: What the new dynamics of business ecosystems mean for strategy, innovation and sustainability. Harvard Business School Press.

Isenberg, D. (2010). How to start an entrepreneurial revolution. Harvard Business Review, 88(6), 40-50.

Isenberg, D. (2011). The entrepreneurship ecosystem strategy as a new paradigm for economy policy: Principles for cultivating entrepreneurship. Babson Entrepreneurship Ecosystem Project, Babson College.

Isenberg, D., \& Onyemah, V. (2016). Fostering scaleup ecosystems for regional economic growth (innovations case narrative: Manizales-mas and scale up Milwaukee). Innov. Technol. Governance Glob., 11, 60-79.

Katz B., \& Bradley, J. (2013). The Metropolitan Revolution: How Cities and Metros Are Fixing Our Broken Politics and Fragile Economy. Reprint ed. Brookings Institution Press.

Kaufmann, D., \& Siegelbaum, P. (1997). Privatization and corruption in transition economies. Journal of International Affairs, 50(2), 419-458.

Kolvereid, L., \& Isaksen, E. J. (2017). Expectations and achievements in new firms. Journal of Small Business and Enterprise Development, 24(3), 649-668.

Kremer, K. (2019). The entrepreneurial ecosystem: A country comparison based on the GEI approach. DICE Report, 17, 52-62.

Kshetri, N. (2014). Developing successful entrepreneurial ecosystems: Lessons from a comparison of an Asian Tiger and a Baltic Tiger. Baltic Journal of Management, 9(3), 330-356.

Kuckertz, A. (2019). Let's take the entrepreneurial ecosystem metaphor seriously! Journal of Business Venturing Insights, 11(C), 1-7.

Levie, J., \& Autio, E. (2008). Regulation of entry, rule of law, and entrepreneurship: an international panel study. Hunter Centre for Entrepreneurship working paper. University of Strathclyde.

Lowe, N., \& Feldman, M. (2017). Institutional life with an entrepreneurial region. Geography Compass, 11, e12306.

Malecki, E. J. (2018). Entrepreneurship and entrepreneurial ecosystems. Geography Compass, 12(3), e12359.

McCaffrey, M., \& Salerno, J. (2011). A theory of political entrepreneurship. Modern Economy, 2(4), $552-560$.

Méon, P. G., \& Sekkat, K. (2005). Does corruption grease or sand the wheels of growth? Public Choice, 122(1-2), 69-97. 
Miles, M. P., \& Morrison, M. (2018). An effectual leadership perspective for developing rural entrepreneurial ecosystems. Small Business Economics, 54(4), 933-949.

Moore, J. F. (1993). Predators and prey: A new ecology of competition. Harvard Business Review, 71(3), 75-86.

Mthanti, T., \& Ojah, K. (2017). Entrepreneurial orientation (EO): Measurement and policy implications of entrepreneurship at the macroeconomic level. Research Policy, 46(4), 724-739.

National Institute of Statistics (2020). Resident population on January 1, 2020 and international migration in 2019. Retrieved December 27, 2020, from: https://insse.ro/cms/en/content/resident-population-janua ry-1-2020-and-international-migration-2019.

Neck, H. M., Meyer, G. D., Cohen, B., \& Corbett, A. C. (2004). An entrepreneurial system view of new venture creation. Journal of Small Business Management, 42(2), 190-208.

Nicotra, M., Romano, M., Del Giudice, M., \& Schillaci, C. E. (2017). The causal relation between entrepreneurial ecosystem and productive entrepreneurship. The Journal of Technology Transfer, 43(1), 640-673.

North, D. (1990). Institutions, institutional change and economic performance. Cambridge University Press.

Porter, M. E. (1998). Clusters and the new economics of competition. Harvard Business Review, 76(6), 77-91.

Pugh, R., Soetanto, D., Jack, S. L., \& Hamilton, E. (2019). Developing local entrepreneurial ecosystems through integrated learning initiatives: The Lancaster case. Small Business Economics. https://doi.org/ 10.1007/s11187-019-00271-5.

Roundy, P. T., Brockman, B. K., \& Bradshaw, M. (2017). The resilience of entrepreneurial ecosystems. Journal of Business Venturing Insights, 8(C), 99-104.

Sauka, A., \& Welter, F. (2007). Productive, unproductive and destructive entrepreneurship in an advanced transition setting: The example of Latvian small enterprises. In M. Dowling \& J. Schmude (Eds.), Empirical entrepreneurship in Europe: New perspectives (pp. 87-111). Edward Elgar Publishing.

Schumpeter, J. A. (1934). The theory of economic development. Harvard University Press.

Shleifer, A., \& Vishny, R. (1993). Corruption. Quarterly Journal of Economics, 108(3), 599-617.

Shleifer, A., \& Vishny, R. W. (2002). The grabbing hand: Government pathologies and their cures. Harvard University Press.

Simmons, S. A., Wiklund, J., Levie, J., Bradley, S. W., \& Sunny, S. A. (2019). Gender gaps and re-entry into entrepreneurial ecosystems after business failure. Small Business Economics, 53(2), 517-531.

Spigel, B. (2016). Developing and governing entrepreneurial ecosystems: The structure of entrepreneurial support programs in Edinburgh, Scotland. Journal of Innovation and Regional Development, 7(2), $141-160$.

Spigel, B. (2017). The relational organization of entrepreneurial ecosystems. Entrepreneurship Theory and Practice, 41(1), 49-72.

Spigel, B., \& Harrison, R. (2018). Toward a process theory of entrepreneurial ecosystems. Strategic Entrepreneurship Journal, 12(1), 151-168.

Spigel, B., Kitagawa, F., \& Mason, C. (2020). A manifesto for researching entrepreneurial ecosystems. Local Economy, 35(5), 482-495.

Stam, E. (2015). Entrepreneurial ecosystems and regional policy: A sympathetic critique. European Planning Studies, 23(9), 1759-1769.

Stam, E. (2018). Measuring entrepreneurial ecosystems. In Entrepreneurial ecosystems (pp. 173-197). Springer.

Stam, E., \& Van de Ven, A. (2020). Entrepreneurial Ecosystem Elements. Small Business Economics. https:// doi.org/10.1007/s11187-019-00270-6.

Stam, E., Hartog, C., Van Stel, A., \& Thurik, R. (2011). Ambitious entrepreneurship, high-growth firms and macroeconomic growth. In M. Minniti (Ed.), The dynamics of entrepreneurship: Evidence from global entrepreneurship monitor data (pp. 231-249). Oxford University Press.

Szerb, L., Aidis, R., \& Acs, Z. (2013). The comparison of the global entrepreneurship monitor and the global entrepreneurship and development index. Methodologies, Foundations and Trends® in Entrepreneurship, 9(1), 1-142.

Szerb, L., Lafuente, E., Horvath, K., \& Pager, B. (2019). The relevance of quantity and quality entrepreneurship for regional performance: The moderating role of the entrepreneurial ecosystem. Regional Studies, 53(9), 1308-1320.

The Economist (2019). Eastern Europe since 1989, Thirty years of freedom, warts and all. The Economist, 2 November, p. 29. 
Theodoraki, C., \& Messeghem, K. (2017). Exploring the entrepreneurial ecosystem in the field of entrepreneurial support: A multi-level approach. International Journal of Entrepreneurship and Small Business, 31(1), 47-66.

Treisman, D. (2000). The causes of corruption: A cross-national study. Journal of Public Economics, 76(3), 399-457.

Van der Zwan, P., Verheul, I., \& Thurik, A. R. (2012). The entrepreneurial ladder, gender, and regional development. Small Business Economics, 39(3), 627-643.

Vedula, S., \& Kim, P. H. (2019). Gimme shelter or fade away: The impact of regional entrepreneurial ecosystem quality on venture survival. Industrial and Corporate Change, 28, 827-854.

Villegas-Mateos, A. (2020). Regional entrepreneurial ecosystems in Chile: comparative lessons. Journal of Entrepreneurship in Emerging Economies, 13(1), 39-63.

Webb, J. W., Khoury, T. A., \& Hitt, M. A. (2019). The influence of formal and informal institutional voids on entrepreneurship. Entrepreneurship Theory and Practice, 44(3), 504-526.

Weitzel, U., Urbig, D., Desai, S., Sanders, M., \& Acs, Z. (2010). The good, the bad, and the talented: Entrepreneurial talent and selfish behavior. Journal of Economic Behavior \& Organization, 76(1), 64-81.

World Economic Forum (2019). Global Competitiveness Report. Retrieved December 27, 2020, from https:// www.weforum.org/reports/how-to-end-a-decade-of-lost-productivity-growth

Publisher's note Springer Nature remains neutral with regard to jurisdictional claims in published maps and institutional affiliations.

\title{
Authors and Affiliations
}

\author{
Maksim Belitski ${ }^{1,2}$ - Ana-Maria Grigore ${ }^{3} \cdot$ Anca Bratu $^{3}$ \\ Ana-Maria Grigore \\ ana.grigore@faa.unibuc.ro \\ Anca Bratu \\ anca.bratu@faa.unibuc.ro \\ 1 ICD Business School, IGS-Groupe, rue A. Parodi, 12, Paris, France \\ 2 Henley Business School, University of Reading, Reading, UK \\ 3 University of Bucharest, Bucharest, Romania
}

